\title{
Obesity and breast cancer: inflammatory and adipocytokine correlations
}

\author{
Paulo C Matafome ${ }^{1,2,3,6^{*}}$, Ana L Gomes ${ }^{1}$, Manuel Gomes ${ }^{4}$, Lélita C Santos ${ }^{4}$, Ana B Sarmento ${ }^{5,6}$, Raquel F Seiça $a^{1,3,6}$ \\ From 16th International Charles Heidelberger Symposium on Cancer Research \\ Coimbra, Portugal. 26-28 September 2010
}

Obesity is a chronic disease affecting millions of individuals around the world and has taken epidemic proportions. Often, obesity is associated with other risk factors such as hypertension and dyslipidemia, increasing metabolic syndrome- related complications. Such complications include several cancer types, namely breast cancer. Several mechanisms are likely to be involved in cancer development and progression, however obesity as been proved to be a risk factor. This study was designed in order to analyse metabolic, inflammatory and oxidative stress correlations between obesity and breast cancer, studying three groups of patients: obesity, breast cancer and obesity plus breast cancer.

Our results revealed no significant metabolic changes between groups, despite some increased glycemia and lipid levels were observed in obesity plus cancer group. Furthermore, obesity plus cancer patients showed increased fasting insulin levels and insulin resistance. Regarding inflammatory biomarkers there were observed no differences in TNF-alpha, IL-6, IL-8 and IL-10. However, MCP-1 levels were found to be increased in obese patients with cancer, suggesting an involvement in obesity- associated tumours. Serum levels of adiponectin were similar in all groups and leptin levels were directly correlated with the BMI. However, resistin levels were increased in obese plus cancer group following MCP-1 profile.

This work revealed some biological markers of breast cancer in obese woman, suggesting dysfunctional adipose tissue as the link between obesity and cancer.

\section{Author details}

${ }^{1}$ Institute of Physiology, Faculty of Medicine, University of Coimbra, Coimbra, Portugal. ${ }^{2}$ Center of Ophthalmology, Faculty of Medicine, University of Coimbra, Coimbra, Portugal. ${ }^{3}$ Institute of Biomedical Research in Light and Image (IBILI), Faculty of Medicine, University of Coimbra, Coimbra, Portugal. ${ }^{4}$ Department of Internal Medicine, University Hospitals, Coimbra, Portugal.

${ }^{5}$ Institute of Biochemistry, Faculty of Medicine, University of Coimbra, Coimbra, Portugal. ${ }^{6} \mathrm{CIMAGO}$, Faculty of Medicine, University of Coimbra, Coimbra, Portugal.

Published: 24 September 2010

\section{doi:}

Cite this article as: Matafome et al:: Obesity and breast cancer: inflammatory and adipocytokine correlations. BMC Proceedings 20104 (Suppl 2):P5.

\footnotetext{
* Correspondence: paulomatafome@gmail.com

${ }^{1}$ Institute of Physiology, Faculty of Medicine, University of Coimbra, Coimbra, Portugal

Full list of author information is available at the end of the article
}

Submit your next manuscript to BioMed Central and take full advantage of:

- Convenient online submission

- Thorough peer review

- No space constraints or color figure charges

- Immediate publication on acceptance

- Inclusion in PubMed, CAS, Scopus and Google Scholar

- Research which is freely available for redistribution

Submit your manuscript at www.biomedcentral.com/submit
C Biomed Central 